\title{
Timing of Pistacia chinensis Bunge. Rooting Using Morphological Markers Associated with Calendar Date and Degree Days
}

\author{
Diane E. Dunn', Janet C. Cole' ${ }^{2}$ and Michael W. Smith ${ }^{3}$ \\ Department of Horticulture and Landscape Architecture, Oklahoma State University, Stillwater, \\ OK 74078
}

\begin{abstract}
Additional index words. Chinese pistache, heat units, propagation
Abstract. The objective of this study was to determine the most advantageous time to collect cuttings of Chinese pistache, a commonly recommended ornamental shade tree that is difficult to propagate by cuttings. In 1993, calendar date and degree days (daily mean temperature $\mathbf{- 7 . 2 C}$ ) were used to estimate an appropriate cutting time. The greatest percentage of rooted cuttings occurred in male cuttings harvested on 13 May 1993 (397 degree days) and treated with 17,500 mg·liter ${ }^{-1}$ IBA or in male cuttings harvested on 20 May 1993 (482 degree days) and treated with either 8750 or 17,500 mg.liter ${ }^{-1}$ IBA. In 1994, cutting time was associated with calendar days, degree days, and morphology. The most rooted cuttings $(44 \%$ ) were from green softwood cuttings taken on 9 May 1994, which was 380 degree days from orange budbreak using a threshold temperature of 7.2C. Orange budbreak was characterized by separation of the outer bud scales such that the orange, pubescent inner bud scales were visible. Cuttings taken on 9 May 1994 and treated with 8750 mg.liter${ }^{1}$ IBA produced the most primary and secondary roots and the longest primary roots per cutting. Male Chinese pistache cuttings should be collected from green softwood or red semi-softwood stems when about 380 to 573 degree days have accumulated after orange budbreak. Chemical names used: indolebutyric acid (IBA).
\end{abstract}

Chinese pistache is hardy in USDA hardiness zones 6 through 9 (Dirr, 1990), flourishes in full sun, and reaches a mature height of 9 to $12 \mathrm{~m}$ with a 4.2 - to $9-\mathrm{m}$ spread (Whitcomb, 1985). This tree is native to well-drained, alkaline soils and is tolerant of many soil conditions (Lee et al., 1976a). It is recommended for its drought hardiness, salt tolerance, and extreme heat and wind tolerance (Dewers, 1981; Behboudian et al., 1986). Furthermore, the tree endures winter temperatures to -26C (Koller, 1978). As a street tree, it continues healthy growth even when planted on narrow spacings (Long, 1960). Most trees display shades of brilliant orange-red, although extreme diversity in coloration can exist even within the same tree (MacMillian Browse, 1988). Foliage is lush throughout the season and does not suffer any major insect or disease problems (Dirr, 1990; Whitcomb, 1985).

Currently, Chinese pistache trees are propagated from seed. Unfortunately, however, there is no dependable seed source for this species (MacDonald, 1986). Asexual reproduction of Chinese pistache would allow selection of cultivars having desirable characteristics such as reliable cold hardiness, vivid fall color, strong branching habit, and interesting bark texture. Male Chinese pistache cultivars could also be marketed for use in locations where fruitless trees are needed.

Adult cuttings of Chinese pistache are difficult to root. However, there has been some rooting success with cuttings from juvenile seedlings (Lee et al., 1976b; Pair and Khatamian, 1982). Attempts to root Pistacia vera $\mathrm{L}$. cuttings from adult trees have been limited or unsuccessful with high concentrations of indolebutyric acid (IBA) (Al Barazi and Schwabe, 1982, 1984, 1985).

Received for publication 17 May 1995. Accepted for publication 27 Nov. 1995 Approved for publication by the director of the Oklahoma Agricultural Experiment Station. This research was supported under project H-2436. The cost of publishing this paper was defrayed in part by the payment of page charges. Under postal regulations, this paper therefore must be hereby marked advertisement solely to indicate this fact.

${ }^{1}$ Graduate research assistant.

${ }^{2}$ Associate professor.

${ }^{3}$ Professor.
Juvenility in Chinese pistache seems to be lost after two years (Lee, et al., 1976b; Pair and Khatamian, 1982), making asexual propagation thereafter more difficult.

Proper timing is crucial to rooting success in many woody species. Methods for predicting optimum cutting time for various species include use of calendar date (Barnes and Lewandowski, 1991; Burd and Dirr, 1977), number of calendar days past budbreak (MacDonald, 1986; Whitcomb, 1982), degree day chillingunits (Major and Grossnickle, 1990), morphological condition of the cutting (Adams and Roberts, 1967), use of indicator plants (Congdon, 1965), and photoperiod (Butcher and Wood, 1984). Estimates of appropriate cutting time by degree day heat-units have not been documented, but they are commonly used to predict budbreak (Sparks, 1993; Spiers, 1976), leaf emergence (Eisensmith, et al., 1980), flowering (Anstey, 1966; Mainland, 1986), and harvest time (Addison, 1969; Fisher, 1962).

The objective of this study was to determine if a window of rootability exists for Chinese pistache which can be defined using calendar days, degree days, or morphological markers so that appropriate cutting dates could be determined regardless of geographic location.

\section{Materials and Methods}

Calendar timing. Cuttings were collected from two 34-year-old male and two 34-year-old female trees at 2-week intervals from 13 May 1993 through 24 Aug. 1993. Cuttings were immediately placed in 10C tap water, taken to a greenhouse and recut to $10 \mathrm{~cm}$ long. The basal $1 \mathrm{~cm}$ of the cuttings was dipped for $5 \mathrm{sec}$ in 17,500 $\mathrm{mg} \cdot$ liter $^{-1}$ IBA. The auxin solution was prepared by dissolving the appropriate amount of IBA in $50 \mathrm{ml}$ of $70 \%$ isopropyl alcohol then using tap water to bring the solution to $100 \mathrm{ml}$. After auxin treatment, cuttings were placed in $12 \mathrm{~cm}$ wide $\times 36 \mathrm{~cm}$ long $\times 6 \mathrm{~cm}$ deep plastic rooting flats containing 1 peat : 4 perlite (by volume) and then kept in a polyethylene greenhouse under natural photoperiod with a maximum photosynthetic photon flux (PPF) of 845 $\mu \mathrm{mol} \cdot \mathrm{m}^{-2} \cdot \mathrm{s}^{-1}$ and maximum/minimum air temperatures of $36 / 13 \mathrm{C}$. 
Table 1. Observation, bud diameter, number of calendar days from budbreak, and degree days using a threshold temperature of 7.2C from budbreak of various morphological characteristics of Chinese pistache in 1994.

\begin{tabular}{|c|c|c|c|c|c|}
\hline Date & $\begin{array}{l}\text { Morphological } \\
\text { marker }\end{array}$ & $\begin{array}{c}\text { RHS color } \\
\text { chart description } \\
\text { of stem color }\end{array}$ & $\begin{array}{l}\text { Bud } \\
\text { diam } \\
(\mathrm{mm})^{\mathrm{y}}\end{array}$ & $\begin{array}{l}\text { Calendar } \\
\text { days from } \\
\text { budbreak }^{\mathrm{x}}\end{array}$ & $\begin{array}{c}\text { Degree } \\
\text { days from } \\
\text { budbreak }^{\mathrm{x}}\end{array}$ \\
\hline 18 Mar. & Dormant terminal bud & Greyed-Green 197D & 4.6 & --- & --- \\
\hline 24 Mar. & Orange budbreak & Greyed-Green 197D & 4.8 & --- & --- \\
\hline 04 Apr. & Green budbreak & Greyed-Green 197D & --- & 11 & 31 \\
\hline 11 Apr. & Closed cone & Greyed-Green 197D & --- & 18 & 73 \\
\hline 16 Apr. & Open cone & Greyed-Green 197D & --- & 23 & 123 \\
\hline 20 Apr. & Bud completely open & Greyed-Green 197D & --- & 27 & 177 \\
\hline 24 Apr. & Early shoot expansion & Yellow-Green 144B & 1.7 & 31 & 249 \\
\hline 09 May & Green softwood stem & Yellow-Green 144B & 2.8 & 46 & 380 \\
\hline 25 May & Red semi-soft stem & Greyed-Red 181B & 3.6 & 62 & 573 \\
\hline 07 June & Red semi-hard stem & Greyed-Orange 174B & 4.0 & 75 & 799 \\
\hline 06 July & Brown semi-hard stem & Greyed-Orange 164B & 4.2 & 104 & 1371 \\
\hline 05 Aug. & Brown hardwood stem & Greyed-Orange 164B & 4.1 & 134 & 1937 \\
\hline 16 Nov. & Dormant terminal bud & Greyed-Green 197A & 4.3 & 237 & --- \\
\hline
\end{tabular}

${ }^{\mathrm{z}}$ Royal Horticultural Society color charts.

yMean of 10 replications. Buds measured were the third bud basipetal to the terminus.

${ }^{\mathrm{x}}$ Budbreak is considered to be when the outer bud scales open and the orange inner bud scales are showing.

Flats were placed on benches equipped with Flora Mist nozzles (A.H. Hummert, St. Louis) with an output of 32 liters/h placed 50 $\mathrm{cm}$ above the flats at $121-\mathrm{cm}$ intervals. Mist cycles were adjusted as necessary to allow foliage to dry before misting, and averaged 2 -sec duration every 8 min between 0800 and 1800 HR daily.

Degree days were calculated from 15 Mar. 1993 to the cutting date using the following formula: [(daily maximum temperature + minimum temperature) $/ 2$ - threshold temperature]. A threshold temperature of 7.2C was used (Baker and Brooks, 1994; Brown, 1952). Degree day calculations began 15 Mar. 1993 because this was the earliest date in which daily temperatures were consistently warm enough to accumulate degree day heat units using a 7.2C threshold. The 15 Mar. 1993 date was before budbreak.

A split-block design was used with 3 replications of 10 subsamples per treatment combination. Gender was the main plot and cutting date the subplot. Cuttings were evaluated 12 weeks after planting using the following rating scale: $0=$ dead, $1=$ no callus or roots, $2=$ callus present, $3=$ roots present. Statistical analysis was performed using analysis of variance (ANOVA) with mean separation by the protected least significant difference (LSD) procedure.

A second study was conducted using cuttings harvested on 13 or 20 May from the same male and female trees. Cuttings were treated with either 8750 or $17,500 \mathrm{mg} \cdot$ liter $^{-1}$ IBA. Treatment combinations were replicated three times with 10 subsamples per replication. The experimental design was a split plot with gender and IBA concentration as the main plots and cutting date as the subplot. Other conditions were identical to those described earlier.

Morphology and degree days. Morpho-

Fig. 1. Morphological changes in Chinese pistache cuttings from 18 Mar. through 4 Apr. (A) 18 Mar., dormant terminal bud; (B) 24 Mar., orange budbreak with outer bud scales open and pubescent orange inner buds closed; (C) 4 Apr., green budbreak, with pubescent orange inner bud scales open and green leaf tissue exposed. logical changes of one 17-year-old male Chinese pistache tree at the Oklahoma State Univ. Nursery Research Station, Stillwater, Okla. were documented from 18 Mar. 1994 through 16 Nov. 1994 (Table 1, Fig. 1). Cuttings were collected on dates which corresponded to the morphological conditions indicated in Table 1. Terminal cuttings from lateral shoots were harvested from the upper canopy. Cuttings were treated as described above except that they were recut to $9 \mathrm{~cm}$ long immediately below a reproductive bud then the basal $1 \mathrm{~cm}$ was dipped for $5 \mathrm{sec}$ in a solution of 1) tap water-no auxin, 2) $8750 \mathrm{mg} \cdot$ liter $^{-1} \mathrm{IBA}$, 3) $17,500 \mathrm{mg} \cdot$ liter $^{-1} \mathrm{IBA}$, or 4) $35,000 \mathrm{mg} \cdot \mathrm{liter}^{-1}$ IBA. Cuttings were placed in $25 \mathrm{~cm}$ wide $\times$ $16 \mathrm{~cm}$ long $\times 8 \mathrm{~cm}$ deep plastic flats and placed under the environmental conditions described above, except that benches were equipped with DGT nozzles (A.H. Hummert) with an output of 2 liters/min and maximum/minimum air temperatures were 38/ 22C. Diameter of the third bud basipetal to the terminal was measured on one randomly selected cutting from each flat.

Visible morphological changes were recorded throughout the growing season. Stem color was based on Royal Horticultural
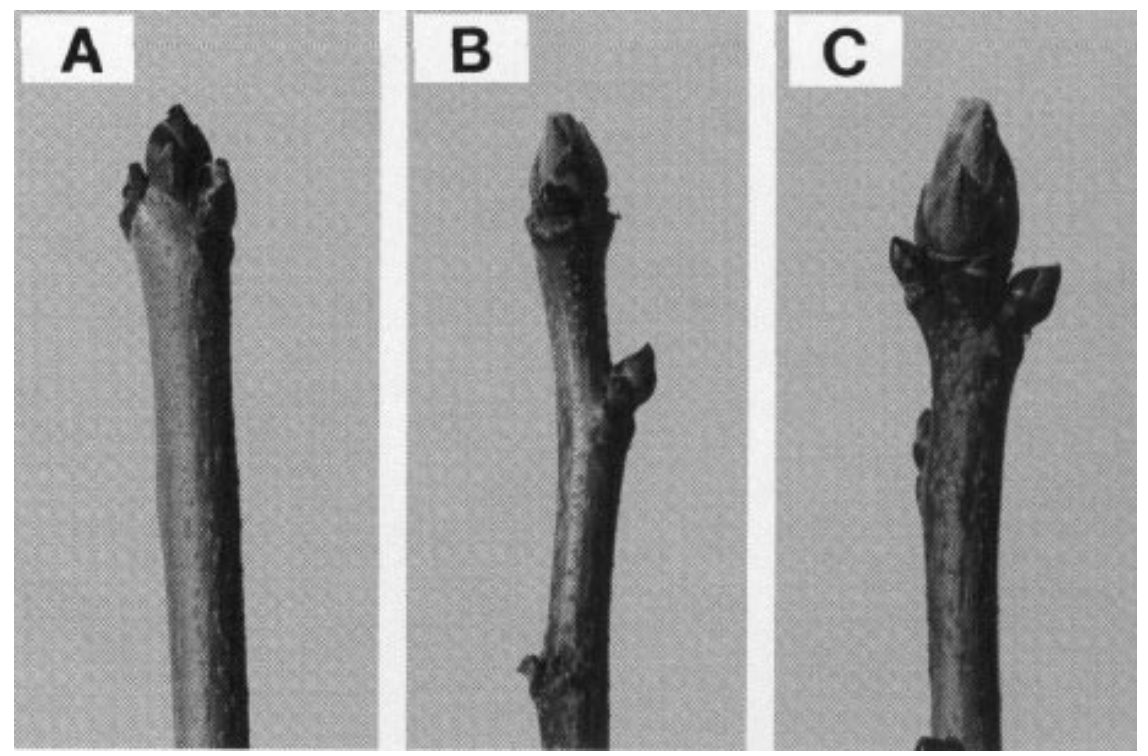
Table 2. Visual root rating and percentage of cuttings rooted 12 weeks after planting male and female Chinese pistache cuttings that were harvested at 2-week intervals in 1993 and treated with 17,500 mg $\cdot$ liter $^{-1}$ IBA. Rating scale: $0=$ dead, $1=$ no callus, no roots, 2 = callus present, and $3=$ roots present.

\begin{tabular}{|c|c|c|c|c|}
\hline Cutting date & Degree days & Tree gender & Visual root rating & Percent rooted \\
\hline \multirow[t]{2}{*}{13 May } & 397 & Male & 2.3 & 33.3 \\
\hline & & Female & 1.8 & 0.0 \\
\hline \multirow[t]{2}{*}{20 May } & 482 & Male & 2.5 & 50.0 \\
\hline & & Female & 2.0 & 3.3 \\
\hline \multirow[t]{2}{*}{1 June } & 642 & Male & 1.8 & 0.0 \\
\hline & & Female & 1.7 & 0.0 \\
\hline \multirow[t]{2}{*}{16 June } & 887 & Male & 1.8 & 10.0 \\
\hline & & Female & 2.2 & 16.7 \\
\hline \multirow[t]{2}{*}{2 July } & 1196 & Male & 1.4 & 0.0 \\
\hline & & Female & 1.5 & 0.0 \\
\hline \multirow[t]{2}{*}{13 July } & 1421 & Male & 0.2 & 0.0 \\
\hline & & Female & 1.3 & 0.0 \\
\hline \multirow[t]{2}{*}{27 July } & 1725 & Male & 1.0 & 0.0 \\
\hline & & Female & 1.0 & 0.0 \\
\hline \multirow[t]{2}{*}{10 Aug. } & 2006 & Male & 1.2 & 0.0 \\
\hline & & Female & 1.5 & 0.0 \\
\hline \multirow[t]{2}{*}{24 Aug. } & 2326 & Male & 1.0 & 0.0 \\
\hline & & Female & 1.0 & 0.0 \\
\hline \multicolumn{5}{|c|}{ Significance $\left(\mathrm{LSD}_{0.05}\right)$} \\
\hline \multicolumn{2}{|c|}{ Gender for the same date } & & 1.2 & \\
\hline \multicolumn{2}{|c|}{ Gender for different dates } & & 3.6 & \\
\hline
\end{tabular}

Society (RHS) color charts and recorded for five random cuttings per observation time (Table 1), with photographs illustrating the morphological condition from 18 Mar. through 4 Apr. (Fig. 1). Calendar days and degree days were calculated from orange budbreak (Table 1) to the date the morphological change was observed or cutting date. Degree days were calculated as described above.

A split-block design was used with 10 replications of 5 subsamples for each cutting date. IBA concentration was the main plot and cutting time was the subplot. Cuttings were evaluated 12 weeks after planting for primary root number, length of three longest primary roots, and number of secondary roots on three longest primary roots. Cuttings were rated using the previously described rating scale. Analysis of variance procedures (GLM) were performed on visual ratings using SAS statistical software (SAS Institute, Cary, N.C.). Protected LSD values were determined for visual ratings and means and standard errors were calculated for primary root number and length and secondary root number on cuttings that rooted.

\section{Results}

Calendar timing. There was a significant interaction between cutting date in 1993 and tree gender for visual root rating (Table 2) with cuttings harvested from male trees on 13 or 20 May 1993 (397 or 482 degree days (DD), respectively) having higher root ratings and rooting percentages than cuttings harvested from either male or female trees on 27 July and 24 Aug. 1994 (1725 and 2006 DD). Regardless of gender, no rooting occurred on cuttings harvested on or after 2 July (1196 DD).

There was a significant interaction between cutting date, tree gender and IBA concentration for visual root rating (Table 3). Cuttings that were harvested 13 May (397 DD) from male trees and treated with $8750 \mathrm{mg} \cdot \mathrm{liter}^{-1}$ had a significantly lower visual root rating than those harvested on the same date from male trees and

Table 3. Visual root ratings and percentage of cuttings rooted 12 weeks after treating the basal $1 \mathrm{~cm}$ of male and female Chinese pistache cuttings with 8750 or $17,500 \mathrm{mg} \cdot \mathrm{liter}^{-1} \mathrm{IBA}$ and planting on 13 and 20 May 1993. Rating scale: $0=$ dead, $1=$ no callus, no roots, $2=$ callus present, and $3=$ roots present.

\begin{tabular}{|c|c|c|c|c|c|}
\hline $\begin{array}{l}\text { Cutting } \\
\text { date }\end{array}$ & $\begin{array}{c}\text { Degree } \\
\text { days }\end{array}$ & $\begin{array}{l}\text { Tree } \\
\text { gender }\end{array}$ & $\begin{array}{l}\text { IBA concn } \\
\left(\mathrm{mg} \cdot \text { liter }^{-1}\right)\end{array}$ & $\begin{array}{l}\text { Visual root } \\
\text { rating }\end{array}$ & $\begin{array}{r}\text { Percent } \\
\text { rooted }\end{array}$ \\
\hline \multirow[t]{4}{*}{13 May } & 397 & Male & 8,750 & 0.9 & 3.3 \\
\hline & & & 17,500 & 2.3 & 33.3 \\
\hline & & Female & 8,750 & 1.5 & 3.3 \\
\hline & & & 17,500 & 1.8 & 0.0 \\
\hline \multirow[t]{4}{*}{20 May } & 482 & Male & 8,750 & 2.4 & 40.0 \\
\hline & & & 17,500 & 2.5 & 50.0 \\
\hline & & Female & 8,750 & 2.1 & 13.3 \\
\hline & & & 17,500 & 2.0 & 3.3 \\
\hline \multicolumn{6}{|c|}{ Significance $\left(\mathrm{LSD}_{0.05}\right)$ : } \\
\hline \multicolumn{3}{|c|}{ Concentration and gender for the same date } & & 1.1 & \\
\hline \multicolumn{3}{|c|}{ Concentration and gender for different dates } & & 1.3 & \\
\hline
\end{tabular}


Table 4. Sources of variation and significance for visual root rating in 1994. Treatment means are shown in Table 5.

\begin{tabular}{lrc}
\hline \hline Source of variation & df & Sum of squares \\
\hline Block & 9 & $10.87^{* * *}$ \\
IBA (I)-linear (L) & 1 & 1.82 \\
I-quadratic (Q) & 1 & $5.35^{* *}$ \\
I-cubic (C) & 1 & $5.90^{* *}$ \\
Error A & 27 & 14.99 \\
Date (D) & 7 & $564.98^{* * *}$ \\
D $\times$ I-L & 7 & 4.25 \\
D $\times$ I-Q & 7 & $9.99^{* *}$ \\
D $\times$ I-C & 7 & $8.05^{* *}$ \\
Error B & 252 & 107.16 \\
\hline
\end{tabular}

treated with 17,500 mg.liter ${ }^{-1}$ and those harvested on 20 May (482 DD) from male trees and treated with either IBA concentration. There was no significant difference in visual root rating of female trees regardless of cutting date or IBA concentration.

Morphology and degree days. The interaction of IBA with cutting date was significant at $P \leq 0.01$ (Table 4 ). Green softwood cuttings taken on 9 May 1994, (380 DD after orange budbreak) and receiving $8750 \mathrm{mg} \cdot \mathrm{liter}^{-1} \mathrm{IBA}$ had the highest root rating with the most rooted cuttings $(44 \%)$ compared to cuttings harvested on all other dates, except 25 May (Table 5). The largest number of primary and secondary roots and longest primary roots occurred on cuttings harvested on 9 May and treated with $8750 \mathrm{mg} \cdot$ liter $^{-1}$ IBA. With the exception of one cutting on 6 July, rooting only occurred when cuttings were taken between orange budbreak and red semihardwood stems (0 to 799 DD). No rooting occurred when the parent plants had been exposed to more than 799 DD.

\section{Discussion}

Many cuttings, including Acer palmatum Thunb., Betula nigra L., Betula pendula Roth, Fraxinus spp. and cultivars, Ulmus

Table 5. Effect of cutting date and IBA concentration on visual root rating in 1994 using a scale of 0 to 3 in which $0=$ deat, $1=$ no callus, no roots, $2=$ callus present, and $3=$ roots present on Chinese pistache cuttings. The percentage of cuttings rooted was determined and the number and length of primary roots and number of secondary roots on rooted cuttings were evaluated.

\begin{tabular}{|c|c|c|c|c|c|c|c|}
\hline $\begin{array}{l}\text { Cutting } \\
\text { date }\end{array}$ & $\begin{array}{l}\text { Degree } \\
\text { days }^{z}\end{array}$ & $\begin{array}{c}\text { IBA } \\
\text { concn } \\
\left(\mathrm{mg} \cdot \text { liter }^{-1}\right)\end{array}$ & $\begin{array}{l}\text { Visual } \\
\text { root } \\
\text { rating }\end{array}$ & $\begin{array}{c}\text { Percent } \\
\text { rooted }\end{array}$ & $\begin{array}{c}\text { No. of } \\
\text { primary } \\
\text { roots } \\
(\text { mean } \pm \mathrm{SE})\end{array}$ & $\begin{array}{c}\text { Length of } \\
\text { primary roots } \\
(\mathrm{mm}) \\
(\text { mean } \pm \mathrm{SE})\end{array}$ & $\begin{array}{c}\text { No. of } \\
\text { secondary } \\
\text { roots } \\
(\text { mean } \pm \mathrm{SE})\end{array}$ \\
\hline \multirow[t]{4}{*}{18 Mar. } & --- & 0 & 0.6 & 0.0 & & & \\
\hline & & 8,750 & 0.5 & 0.0 & & & \\
\hline & & 17,500 & 0.5 & 0.0 & & & \\
\hline & & 35,000 & 0.7 & 0.0 & & & \\
\hline \multirow[t]{4}{*}{25 Mar. } & --- & 0 & 0.4 & 0.0 & & & \\
\hline & & 8,750 & 0.5 & 0.0 & & & \\
\hline & & 17,500 & 0.5 & 0.0 & & & \\
\hline & & 35,000 & 0.4 & 0.0 & & & \\
\hline \multirow[t]{4}{*}{9 May } & 380 & 0 & 1.9 & 4.0 & $0.0 \pm 0.2$ & $1.1 \pm 5.9$ & $0.0 \pm 0.0$ \\
\hline & & 8,750 & 2.4 & 44.0 & $1.1 \pm 1.9$ & $31.8 \pm 60.2$ & $1.9 \pm 4.2$ \\
\hline & & 17,500 & 1.9 & 12.0 & $0.2 \pm 0.5$ & $9.9 \pm 36.0$ & $0.44 \pm 2.6$ \\
\hline & & 35,000 & 1.8 & 6.0 & $0.1 \pm 0.5$ & $6.4 \pm 31.8$ & $0.2 \pm 0.9$ \\
\hline \multirow[t]{4}{*}{25 May } & 573 & 0 & 1.9 & 2.0 & $0.2 \pm 1.6$ & $1.3 \pm 9.2$ & $0.1 \pm 0.4$ \\
\hline & & 8,750 & 2.1 & 14.0 & $0.4 \pm 1.6$ & $4.4 \pm 20.3$ & $0.2 \pm 1.2$ \\
\hline & & 17,500 & 2.0 & 2.0 & $0.0 \pm 0.1$ & $0.2 \pm 1.4$ & $0.0 \pm 0.0$ \\
\hline & & 35,000 & 1.7 & 0.0 & & & \\
\hline \multirow[t]{4}{*}{7 June } & 799 & 0 & 0.8 & 0.0 & & & \\
\hline & & 8,750 & 1.4 & 0.0 & & & \\
\hline & & 17,500 & 1.1 & 0.0 & & & \\
\hline & & 35,000 & 0.7 & 0.0 & & & \\
\hline \multirow[t]{4}{*}{6 July } & 1371 & 01.1 & 0.0 & & & & \\
\hline & & 8,750 & 1.1 & 2.0 & $0.0 \pm 0.1$ & $3.74 \pm 26.4$ & $0.34 \pm 2.4$ \\
\hline & & 17,500 & 1.1 & 0.0 & & & \\
\hline & & 35,000 & 1.0 & 0.0 & & & \\
\hline \multirow[t]{4}{*}{5 Aug. } & 1937 & 0 & 1.0 & 0.0 & & & \\
\hline & & 8,750 & 0.9 & 0.0 & & & \\
\hline & & 17,500 & 1.0 & 0.0 & & & \\
\hline & & 35,000 & 0.0 & 0.0 & & & \\
\hline \multirow[t]{4}{*}{16 Nov. } & --- & 00.0 & 0.0 & & & & \\
\hline & & 8,750 & 0.0 & 0.0 & & & \\
\hline & & 17,500 & 0.0 & 0.0 & & & \\
\hline & & 35,000 & 0.0 & 0.0 & & & \\
\hline \multicolumn{8}{|c|}{ Significance $\left(\operatorname{LSD}_{005}\right)$} \\
\hline \multicolumn{3}{|c|}{ Date for the same concentration } & 0.6 & & & & \\
\hline \multicolumn{3}{|c|}{ Date for different concentration } & 0.6 & & & & \\
\hline
\end{tabular}

${ }^{\mathrm{z}}$ Based on a threshold temperature of 7.2C (Baker and Brooks, 1944; Brown, 1952). 
parvifolia Jacq., Cotinus coggygria, Scop. and Cercis canadensis L. (Barnes and Lewandowski, 1991), have a short (4-6 weeks) window of rootability. Burd and Dirr (1977) found May and early June cuttings had the highest rooting percentages for mature Malus L. Chinese pistache also appears to have a limited period of rootability during May.

In 1993, cuttings from male Chinese pistache trees consistently rooted more than cuttings from female trees. Similar results were reported on Acer rubrum L. trees (Snow, 1942). Gender did not affect primary or secondary root production, or primary root length, in other Chinese pistache studies (Dunn, 1995).

The degree day (heat-unit) system has been used in horticulture to predict phenological events such as budbreak (Sparks, 1993) and leaf emergence (Eisensmith et al., 1980). Use of degree days from budbreak to predict the most advantageous rooting time has not been previously reported. Major and Grossnickle (1990) used a method of accumulation of chilling units to determine collection time. Using Juniperus, they found that the chilling-unit method can be used to determine rooting ability for plants with a narrow window of opportunity for rooting. Prunus serrulata 'Kwanzan' Lindl. rooting declined more than 30 percent from mid-July to mid-August as stem hardening progressed (Barnes, 1989). In our studies, with the exception of one cutting, rooting was limited to cuttings with green soft stems or red semisoft stems (380 to 573 DD) regardless of IBA treatment. Schmidt (1989) and Barnes and Lewandowski (1991) stated that the status of the shoot harvested for rooting outweighs the effect of chemical treatments. In 1993 cuttings receiving $17,500 \mathrm{mg} \cdot \mathrm{liter}^{-1}$ IBA produced the highest visual root rating, and in 1994, $8750 \mathrm{mg} \cdot \mathrm{liter}^{-1}$ IBA produced the most roots per cutting and the most rooted cuttings.

In conclusion, Chinese pistache has a narrow window of rootability. The greatest potential for root formation occurred 20 May in 1993 and 9 May in 1994. The 20 May 1993 date corresponded to 482 DD while the 9 May date corresponded to $380 \mathrm{DD}$, using a threshold temperature of 7.2C. While the criteria for starting DD calculations differed somewhat by year, rooting potential essentially ended after accumulation of 573 DD each year. Morphologically, the highest percentage of rooted cuttings was from green softwood stems matched to yellow-green 144B on the RHS color chart, with buds about $2.8 \mathrm{~mm}$ in diameter.

\section{Literature Cited}

Adams, D.G. and A.N. Roberts. 1967. A morphological time scale for predicting rooting potential in rhododendron cuttings. Proc. Amer. Soc. Hort. Sci. 91:753-761.

Addison, E.S. 1969. Forecast of blueberry harvest dates as determined by climatology. MS thesis, Rutgers Univ., New Brunswick, N.J.

Al Barazi, Z. and W.W. Schwabe. 1982. Rooting softwood cuttings of adult Pistacia vera L. from seedling tissues. J. Hort. Sci. 57:247-252.

Al Barazi, Z. and W.W. Schwabe. 1984. The possible involvement of polyphenol-oxidase and the auxin-oxidase system in root formation and development in cuttings of Pistacia vera. J. Hort. Sci. 59:453-461.

Al Barazi, Z. and W.W. Schwabe. 1985. Studies on possible internal factors involved in determining ease of rooting in cuttings of Pistacia vera and Prunus avium, cvs. 'Colt' and 'F12/1'. J. Hort. Sci. 60:439-445.

Anstey, T.H. 1966. Prediction of full bloom date for apple, pear, cherry, peach, and apricot from air temperature data. Proc. Amer. Soc. Hort. Sci. 88:57-66.
Baker, G.A. and R.M. Brooks. 1944. Climate in relation to deciduous fruit production in California. III. Effect of temperature on number of days from full bloom to harvest of apricot and prune fruits. Proc. Amer. Soc. Hort. Sci. 45:95-104.

Barnes, H.W. 1989. The use of glycols as solvents for rooting hormones. Proc. Intl. Plant Prop. Soc. 39:517-520.

Barnes, B. and R.J. Lewandowski. 1991. Timing is everything. Amer. Nurseryman 174(8):44-48, 51-53.

Behboudian, M.H., R.R. Walker, and E. Torokfalvy. 1986. Effects of water stress and salinity on photosynthesis of pistachio. Scientia Hort. 29:251-261.

Brown, D.S. 1952. Climate in relation to deciduous fruit production in California. V. The use of temperature records to predict the time of harvest of apricots. Proc. Amer. Soc. Hort. Sci. 60:197-203.

Burd, S.M. and M. Dirr. 1977. Propagation of selected Malus taxa from softwood cuttings. Proc. Intl. Plant Prop. Soc. 27:427-432.

Butcher, S.M., and S.M. Wood. 1984. Vegetative propagation and development of Sophora microphylla. Proc. Intl. Plant Prop. Soc. 2:43-50.

Congdon, M. 1965. Timing and its relation to cutting selection. Comb. Proc. Intl. Plant Prop. Soc. 15:230-232.

Dewers, R.S. 1981. Evaluation of native and exotic woody plants under severe environmental stress. J. Arboricult. 7:299-302.

Dirr, M.A. 1990. Manual of woody landscape plants. 4th ed. Stipes Publishing, Champaign, Ill.

Dunn, D.E. 1995. Vegetative propagation of Chinese pistache. MS thesis., Oklahoma State Univ., Stillwater, Okla.

Eisensmith, S.P., A.L. Jones, and J.A. Flore. 1980. Predicting leaf emergence of 'Montmorency' sour cherry from degree-day accumulations. J. Amer. Soc. Hort. Sci. 105:75-78.

Fisher, D.V. 1962. Heat units and number of days required to mature some pome and stone fruits in various areas of North America. Proc. Amer. Soc. Hort. Sci. 80:114-124.

Koller, G. 1978. New trees for urban landscapes. Arnoldia 38:157-172. Lee, C.I., J.L. Paul, and W.P. Hackett. 1976a. Effect of Ca saturation and air filled porosity of sphagnum peat on the root regeneration of Pistacia chinensis Bunge. and Liquidambar styraciflua L. J. Amer. Soc. Hort. Sci. 101:233-236.

Lee, C.I., J.L. Paul, and W.P. Hackett. 1976b. Root promotion on stem cuttings of several ornamental plants by acid or base pretreatment. Proc. Intl. Plant Prop. Soc. 26:95-99.

Long, D. 1960. Budding and growing Pistacia chinensis for street trees. Proc. Intl. Plant Prop. Soc. 10:294-296.

MacDonald, B. 1986. Practical woody plant propagation for nursery growers. Timber Press. Portland, Ore.

MacMillian Browse, P. 1988. Autumn glory. Knowing and growing the versatile Chinese pistache. Amer. Nurseryman 167(1):115-120.

Mainland, C.M. 1986. Commercial blueberry production guide for North Carolina. North Carolina Agr. Expt. Sta., Raleigh.

Major, J.E. and S.C. Grossnickle. 1990. Chilling units used to determine rooting of stem cuttings of junipers. J. Environ. Hort. 8:32-35.

Pair, J.C. and H. Khatamian. 1982. Propagation and growing of the Chinese pistache. Proc. Intl. Plant Prop. Soc. 32:497-502.

Schmidt, G. 1989. Induction of juvenility and rooting of some woody ornamentals. Proc. Intl. Plant Prop. Soc. 39:250-252.

Snow, G. 1942. Sex and vegetative propagation. J. For. 40:807-808.

Sparks, D. 1993. Chilling and heating model for pecan budbreak. J. Amer. Soc. Hort. Sci. 118:29-35.

Spiers, J.M. 1976. Chilling regimens affect bud break in 'Tifblue' rabbiteye blueberry. J. Amer. Soc. Hort. Sci. 101:84-86.

Whitcomb, C.E. 1982. Nursery research field day. Okla. State Univ. Res. Rpt. P-829.

Whitcomb, C.E. 1985. Know it and grow it. 2nd ed. Lacebark Publications, Stillwater, Okla. 